\title{
Membrii familiei sub lupa preadolescenților
}

\section{Monica OPRIȘ*}

\begin{abstract}
Family members under the magnifying glass of the preadolescents. The media debates in Romania on family issues and their definition emphasised the need for multiple perspective analysis. In the present study we have proposed to carry out a research on issues related to the reporting of the preadolescents to the family members considering, on the one hand, the psychological characteristics of this period in human life, and on the other hand, the external influences that constantly devaluate family. The results of the research confirm the existence of a family crisis at the relational level: most students characterize their family members by statements containing factual data and less on issues that take into account the feelings between them.
\end{abstract}

Keywords: family, preadolescents, family crisis, mass-media.

\section{Preliminarii}

Dezbaterile din mass-media din România pe tema familiei şi a definiţiei acesteia au adus în prim-plan nevoia de analize din perspective multiple ${ }^{1}$. În studiul de faţă ne-am propus să realizăm o cercetare pe aspecte legate de raportarea preadolescenţilor la membrii familiei, date fiind, pe de o parte, caracteristicile psihologice ale acestei perioade din viaţa omului, iar pe de alta, influenţele din exterior care tind să devalorizeze în mod constant familia.

* Prof. dr., Seminarul Teologic Ortodox „Sfântul Simion Ștefan” din Alba Iulia.

${ }^{1}$ Bogdan VoIcu (ed.), Importanţa acordată Familiei, Muncii, Religiei, Timpului liber, Prietenilor, Politicii, în „Valorile românilor”, Newsletter, I.C.C.V., nr. 1, decembrie, 2008. 
Elevii care au format eşantionul de subiecţi au fost rugaţi să formuleze câte un enunţ despre fiecare membru al familiei şi să răspundă la întrebări care să ne permită să desprindem concluzii referitoare la raporturile dintre membrii familiei, pe aspecte legate de lucrurile care îi mulţumesc şi lucrurile care îi nemulţumesc în propria familie ${ }^{2}$. Precizăm faptul că le-am lăsat elevilor libertatea privind definirea extensiunii familiei, în care aceştia au inclus, în structuri şi în procente diferite, părinţii, fraţii, propria persoană, bunicii, unchii, mătuşile sau verişorii.

\section{Caracterizarea membrilor familiei}

Primul aspect avut în vedere în ceea ce priveşte componenţa familiei, conform modului de înţelegere a acesteia de către respondenţi, reflectată de noi în figura 1. Astfel, din eşantionul de 200 de elevi, echilibrat în funcţie de gen, cel mai mare procent de elevi, 43,5\%, au formulat enunţuri despre părinţi şi fraţi $(p, f)$. Un procent mai mic de elevi, $26 \%$, au adăugat în listă şi enunţuri referitoare la propria persoană (p, f, e). Pentru 23\% din elevi şi bunicii au un rol important în conturarea componenţei familiei ( $\mathrm{p}, \mathrm{f}$, b). Un procent mai mic, 7,5, au inclus şi enunţuri referitoare la alte rudenii: unchi şi mătuşi, respectiv la verişori $(\mathrm{p}, \mathrm{f}, \mathrm{r})$.
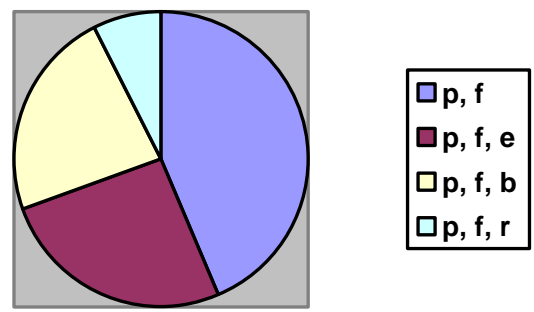

Fig.1. Diagramă de structură privind componenţa familiei reflectată în enunţurile formulate de elevi.

${ }^{2}$ Dorin OPRIŞ, Monica OpRIȘ, Valori, modele, aşteptări ale liceenilor din judeţul Alba, Cluj-Napoca, Edit. Eikon, 2013. 
Din punctul nostru de vedere, prezenţa la aproape o treime dintre elevi a enunţurilor referitoare la familia lărgită, care include rudeniile apropiate - bunici, unchi, mătuşi, verişori, reflectă nevoia de comuniune, dar şi prezenţa activă a acestora în viaţa elevilor. Mai amintim faptul că $4 \%$ dintre elevii chestionaţi fac parte din familii dezmembrate, $5 \%$ au cel puţin un părinte în plecat la lucru în străinătate, $2 \%$ au un părinte decedat.

Majoritatea enunţurilor despre mamă formulate de copii ${ }^{3}$, indiferent de gen, conţin date factuale, referitoare la vârstă şi ocupaţie. $O$ analiză cantitativă pe acest aspect relevă un procent aproape dublu în cazul băieţilor, comparativ cu fetele. Pe lângă aceste date, regăsim - mai ales la fete - şi enunţuri care arată calităţile spirituale şi fizice ale mamei: „Mama este o fiinţă iubitoare.”; „Mama este foarte credincioasă.”; „Mama este bună şi înţelegătoare.”; „Mama este bună la inimă.”; „Mama este o femeie bucuroasă şi grijulie.”; „Mama este o femeie veselă.”; „Mama este frumoasă.”, „Mama are ochi frumoşi şi o privire blândă.”; „Mama este elegantă şi inteligentă.".

Un număr mai mic de răspunsuri relevă aspecte legate de satisfacerea unor nevoi (materiale, spirituale, legate de securitate) ale copiilor: „Mama îmi cumpără haine şi încălţăminte.”; „Mama este bună pentru că îmi cumpără multe lucruri.”; „Mama mă duce în fiecare zi la şcoală.”; „Mama mă iubeşte şi când o supăr.” etc. Sunt şi caracterizări pe aspecte legate de preocupările părinţilor: „Mamei îi place să se uite la televizor.”; „Mamei îi place să gătească.”; „Mamei îi place să facă cumpărături.” etc.

Din răspunsurile elevilor reiese faptul că fetele sunt mult mai atente la detalii referitoare la mamelor lor, decât băieţii, pentru care cele mai importante lucruri sunt legate de locul de muncă al mamei. Acest lucru credem că se datorează în mod semnificativ diminuării constante a implicării copiilor în treburile casnice, cu efecte în timp.

În ceea ce priveşte caracterizarea tatălui, se observă o împărţire echilibrată în funcţie de gen a procentelor pentru

${ }^{3}$ Dorin OpRIŞ, Aspecte privind educaţia religioasă în familia şi în şcoala de azi, în Dorin OPRIŞ, Monica OPRIŞ, „Religia şi educaţia de mâine. Cercetări pedagogice", Cluj-Napoca, Edit. Eikon, 2013, p. 144. 
răspunsurile care prezintă date factuale, legate în special de ocupaţia sau locul de muncă. Tatăl este cel care „lucrează zi şi noapte”, „merge la serviciu în fiecare zi”, „va pleca în Italia să câştige bani ca să ne putem întreţine".

Însuşirile sufleteşti şi fizice sunt mai slab reprezentate. Fetele admiră hărnicia, blândeţea, iar băieţii curajul. Dacă în ceea ce le priveşte pe mame se observă faptul că acestea încearcă să satisfacă în primul rând nevoile materiale ale casei, tatăl este cel care le cumpără copiilor lor într-o mai mare măsură decât mama obiecte care ţin de anumite plăceri ale acestora: jocuri, ciocolată sau alte dulciuri. Băieţii observă abilităţile taţilor lor în repararea unor obiecte (maşini, obiecte de uz casnic etc.). Din răspunsurile elevilor reiese o mai mare disponibilitate a taţilor pentru petrecerea timpului liber cu copiii lor, indiferent de gen: „Tata iese cu mine în parc.”; „Tata mă duce la tenis.”.

În eşantionul nostru, aproape o treime dintre elevi (31\%) sunt singuri la părinţi, $56 \%$ au un frate sau o soră, iar în cazul a $13 \%$ dintre elevi, extensiunea familiei este mai mare. Datele relevă o apropiere mai mare a preadolescenţilor faţă de fraţii mai mari şi de acelaşi gen cu ei. Ei apreciază bunătatea, blândeţea, capacitatea de empatie. Fraţii şi surorile mai mici sunt valorizaţi în măsura în care nu reprezintă o povară pentru ei, prin obligaţia de asumare a unor responsabilităţi în lipsa părinţilor: să îi ia de la şcoală, să le dea mâncare, să îi ajute la teme etc.

Un loc aparte în viaţa copiilor îl au bunicii. Relaţia pe verticală bunici-nepoţi, chiar în dacă societatea postmodernă s-a diminuat, îşi menţine încă rolul formativ de mare importanţă în viaţa copiilor: „Bunica mă învaţă să trăiesc la ţară.”; „Bunica mă învaţă tot ce e bun.”; „Bunica îmi arată multe lucruri.”; „Bunica este darnică.”; „Bunicul se bucură când îl vizităm.”; „Bunicul mă iubeşte.”;

„Bunicul mă învaţă să am grijă de animale.”; „Bunicul se plimbă cu mine.”. Totodată, bunicii sunt valorizaţi de către respondenţi şi pentru faptul că le oferă bani de cheltuială.

Timpul petrecut împreună cu bunicii le oferă elevilor şansa de a învăţa din experienţa de viaţă a acestora, de a-i valoriza, de a se raporta corect la lucruri, de a afla lucruri noi. Faptul că bunicii sunt un 
„depozitar" de cunoştinţe are rolul de a-i motiva pe elevi spre învăţare: „Bunicul este foarte înţelept.”; „Atunci când mă plimb cu bunicul îmi povesteşte foarte multe lucruri.”; „Bunica ştie foarte multe lucruri.”.

Bunicii sunt cei care fac legătura cu strămoşii, care duc tradiţia familiei mai departe: „Bunica îmi vorbeşte despre rădăcinile familiei mele.”; „Bunica îmi vorbeşte despre toate neamurile noastre.”; „La bunici mă întâlnesc cu verişorii mei.”; „Noi mergem la parastasul străbunicilor împreună cu bunicii.”; „Bunica îl îngrijeşte pe străbunicul.”. Asumarea de către unii bunici a rolului de părinţi reprezintă un suport esenţial în dezvoltarea copiilor lăsaţi singuri.

Din răspunsurile elevilor putem desprinde şi date referitoare la modul în care situaţia materială sau alte probleme din familie influenţează raporturile dintre membrii acesteia. De exemplu, un băiat care locuieşte într-o garsonieră doar cu mama lui îşi exprimă nemulţumirea faţă de mediul în care creşte, singurele motive de mulţumire fiind calculatorul şi televizorul. Datele despre el şi despre mama lui sunt de natură factuală. Un alt băiat, crescut de bunica din partea mamei, oferă date doar despre aceasta: pe ea o iubeşte, deoarece 1-a crescut şi îl îngrijeşte, şi este foarte mulţumit că are un câine cu care se joacă.

\section{Motive de mulţumire şi de nemulţumire în propria familie}

Suportul emoţional pe care îl oferă familia este în relaţie şi cu sentimentul de mulţumire pe care îl au membrii acesteia. Atât pentru fete, cât şi pentru băieţi, relaţiile armonioase din cadrul familiei reprezintă principalele motive de mulţumire: „Sunt fericită când stăm toţi împreună.”; ,Vorbim despre multe lucruri împreună şi ne ajutăm, iar asta mă face fericit.”; „Suntem o familie fericită”. Răspunsurile elevilor arată o dată în plus nevoia acestora de stabilitate în plan afectiv.

Alte motive de fericire sunt date de încrederea pe care părinţii le-o acordă: „Mama mă lasă să o ajut la gătit”; „Părinţii mei au încredere în mine”; „Părinţii mei îmi spun că sunt un copil de încredere.”; „Mama mă trimite la cumpărături.”. 
Răspunsurile elevilor oferă o paletă mult mai diversă de motive de nemulţumire: impunerea asumării de responsabilităţi casnice („Părinţii îmi dau câte ceva de lucru prin casă.”), controlul ţinutei şi al vestimentaţiei, realizat în special de mamă (,Mama nu mă lasă să mă îmbrac cum doresc eu.”; „Mama mă ceartă când mă fardez.”; „Mama îmi impune cu ce haine să mă îmbrac.”), relaţiile de dizarmonie dintre fraţi, care, în unele situaţii sunt însoţite de atitudini negative (,Fratele meu nu mă lasă să mă joc cu colegele şi cu verişoarele mele.”; „Sora mea mai mare mă ceartă mereu şi nu mă ajută la teme.”; „Sora mea nu mă ascultă.”; „Mă nemulţumeşte că ne certăm mereu cu toţii.”; „Sora mea mă imită pentru a râde de mine stâlcind cuvinte aşa cum făceam când eram mică şi nu le puteam pronunţa corect.”), nesatisfacerea unor dorinţe (,Părinţii mei mă nemulţumesc atunci când nu îmi cumpără ce îmi doresc.”; „Sunt nemulţumit că nu mă lasă pe calculator.”). În cazul preadolescenţilor cu mai mulţi fraţi motivele suplimentare de nemulţumire sunt date tocmai de provocările date de extensiunea mai mare familiei: mai multe responsabilităţi, nivel social mai scăzut, preluarea garderobei fraţilor mai mari etc.

Chiar dacă apar la un procent mic de elevi (14,5\%), motivele de nemulţumire generate de lipsa relaţiilor armonioase dintre părinţi sunt, din punctul nostru de vedere, cele care îi afectează cel mai mult pe termen lung pe preadolescenţi: „Părinţii mei se ceartă foarte des.”; „Inima mea e ruptă în două deoarece părinţii mei vor să divorţeze.”; „Tata vorbeşte uneori foarte urât cu mama.”; „Pe mine mă nemulţumeşte faptul că mama este separată de tata şi îl văd foarte rar.”; "Tata este plecat toată ziua, iar când vine acasă mereu găseşte un motiv de ceartă.”; „Nimic nu e bine ce face mama.”.

La fel de periculoasă pentru dezvoltarea armonioasă şi pentru crearea unei viziuni sănătoase asupra a ceea ce înseamnă familia este indiferenţa părinţilor faţă de copiii lor: „Tata mă lasă singură şi mă plictisesc.”; „Nu mă ascultă nimeni când vreau şi eu să vorbesc.”; „Mama şi tata sunt prea ocupaţi cu munca şi nu prea mai au timp pentru noi.”; „Eu locuiesc cu bunica, deoarece părinţii sunt plecaţi la muncă în alt oraş". 


\section{Timpul liber împreună cu familia}

Timpul liber este percepute de majoritatea elevilor în relaţie cu vacanţa de vară sau cu sfârşitul de săptămână. În $49 \%$ din răspunsurile elevilor apare cuvântul „vara”, asociat unor acţiuni precum: „mergem la mare”, „mergem la iarbă verde”, „mergem în drumeţii”, „mergem la bazin”, „mergem la pădure”, „facem călătorii”, „facem drumeţii”. Pentru sfârşitul de săptămână, cel mai frecvent $(21 \%)$ apare vizionarea de emisiuni/ filme la televizor, respectiv vizitarea bunicilor. În procente mai mici $(11,5 \%)$, apare participarea la slujbe, la biserica proprie cultului din care elevii fac parte. În timpul săptămânii, copiii merg împreună cu părinţii să mănânce în diferite locuri: mall, pizzerii, cofetării etc.

Analiza acestor răspunsuri reflectă un paradox. Pe de o parte, oferta pentru petrecerea timpului liber este tot mai mare, iar disponibilitatea de a profita, împreună cu toată familia, de acestea este tot mai mică. Din punctul nostru de vedere, una dintre cauzele crizei familiei este tocmai diminuarea intervalului de timp pe care toţi membrii familiei îl petrec împreună. Din răspunsurile elevilor am aflat că, în tot mai multe situaţii, părinţii ajung acasă după ora 18, fapt care diminuează considerabil, în timpul săptămânii, numărul de ore pe care copiii îl petrec împreună cu aceştia (3-4 ore pe zi, dacă scădem orele dedicate odihnei).

Dacă în alte domenii de activitate este valabil principiul conform căruia calitatea este mai importantă decât cantitatea, atunci când ne raportăm la nevoia copilului de afecţiune din partea părinţilor, care implică prezenţă fizică a acestora, acest principiu nu are fundament.

\section{Concluzii}

- Fetele îşi caracterizează mama cu o uşurinţă mai mare decât fac acest lucru pentru tatăl lor, fapt care arată o apropierea mai mare a preadolescentelor de modelul matern. 
- Fetele îşi caracterizează mama pe mult mai multe aspecte decât o fac băieţii de aceeaşi vârstă.

- Taţii încearcă să compenseze numărul de ore mai mic petrecut cu copiii lor prin daruri şi activităţi în afara casei, valorizate de elevi, indiferent de gen. Acest fapt este în măsură să întărească relația tată-copii.

- Pentru majoritatea preadolescenţilor, indiferent de gen, prezenţa fraţilor mai mici reprezintă o mare provocare, dat fiind faptul că la această vârstă sunt priviţi ca o povară, mai ales pe fondul deplasării spre ore tot mai târziu a programului de lucru al părinţilor.

- Fraţii mai mari le oferă preadolescenţilor suport emoţional, dar şi şcolar.

- Preadolescenţii identifică cu o mai mare uşurinţă motive de nemulţumire, diversitatea acestora fiind mult mai mare comparativ cu cele care le aduc mulţumire.

- Motivele de nemulţumire în cadrul familiei relevă dificultăţile tot mai mari în depăşirea provocărilor cu care preadolescenţii se confruntă.

- Preadolescenţii simt nevoia unor modele pentru petrecerea timpului liber, care să valorizeze şi să susţină educaţia formală.

$\cos 80$

\section{Bibliografie}

1. Bocoș, Mușata, OPRIŞ, Dorin, OPRIȘ, Monica, Cercetarea în domeniul educaţiei religioase şi al educaţiei morale. Modele şi aplicaţii, Cluj-Napoca, Edit. Casa Cărţii de Ştiinţă, 2006.

2. COHEN, L., MANION, L., Research Methods in Education, Routledge, London and New-York, 1998.

3. OPRIŞ, Dorin, Aspecte privind educaţia religioasă în familia şi în şcoala de azi, în Dorin OPRIŞ, Monica OPRIŞ, „Religia şi educaţia de mâine. Cercetări pedagogice", Cluj-Napoca, Edit. Eikon, 2013.

4. OPRIŞ, Dorin, Intenţii ale adolescenţilor privind participarea în contexte formale la dezbateri pe teme religioase, în Dorin OPRIŞ, 
Ioan SCHEAU, Octavian MoşıN (ed.), „Educaţia din perspectiva valorilor. Tom XVIII: Summa Paedagogica", Bucureşti, Edit. Eikon, 2020.

5. OPRIŞ, Dorin, OPRIŞ, Monica (coord.), Religia şi şcoala. Cercetări, studii, analize, Bucureşti, Edit. Didactică şi Pedagogică, R.A., 2011.

6. IDEM, Valori, modele, aşteptări ale liceenilor din judeţul Alba, Cluj-Napoca, Edit. Eikon, 2013.

7. OPRIŞ, Monica, Religie, morală, educaţie. Perspective teologice şi pedagogice, Bucureşti, Edit. Basilica a Patriarhiei Române, 2011.

8. OPRIŞ, Monica, Paideia creştină şi educaţia azi, Bucureşti, Edit. Eikon, 2017.

9. OPRIŞ, Monica, OPRIŞ, Dorin, Finalităţi şi conţinuturi pentru educaţia religioasă la liceu: elemente-suport în (re)elaborarea documentelor curriculare, în Octavian Moșin, Ioan SCHEAU, Dorin OPRIŞ (ed.), „Educaţia din perspectiva valorilor. Tom XV: Summa Theologiae", Bucureşti, Edit. Eikon, 2019.

10. VoICU, Bogdan (ed.), Importanţa acordată Familiei, Muncii, Religiei, Timpului liber, Prietenilor, Politicii, în „Valorile românilor”, Newsletter, I.C.C.V., nr. 1, decembrie, 2008. 